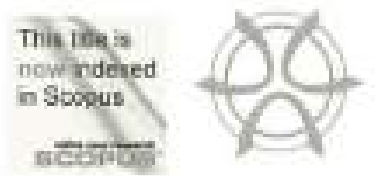

PL.ANNING MALAYSIA

Geosparial Anailysis in Urban Planning

Volume II (2013), Page 57 - 74

\title{
FIRM DYNAMIC ANALYSIS FOR URBAN LAND USE AND ECONOMIC GROWTH MODELLING
}

\section{Noordini Che' Man', Soheil Sabri ${ }^{2}$, Nafisa Hosni ${ }^{3} \&$ Harry Timmermans ${ }^{4}$}

\author{
${ }^{12 d}$ Centre for Innovative Planning and Development (CiPD) \\ UNIVERSITI TEKNOLOGI MALAYSIA \\ ${ }^{4}$ EINDHOVEN UNIVERSITY OF TECHNOLOGY, THE NETHERLANDS
}

\begin{abstract}
In urban growth processes, urbanisation is highly influenced by economic growth which triggers the dynamics of economic agents and land uses. This is consisted of complex subsystems which need sophisticated methods like agent-based modelling and simulation to understand the pattern, behaviour and scale of multiple actors. The objective of this paper is to identify the behaviour, pattern and the scale of impact of firms on market in the region in order to foster an accurate agent-based modelling. The Geographic Information System is utilized to geocode the entrance and exit of firms to the market in Greater Kuala Lumpur region. This study has also carried out a temporal analysis considering 18 years performances of the firms from 1990 to 2007 . The findings in this paper show sector 9 (i.e. Financing) has highest percentage of establishment with $35.1 \%$. In addition, Sector 3 (i.e. Mining) and Sector 5 (i.e. Electricity) have the lowest percentage of establishment with $0.3 \%$. The result of this study will be a foundation to facilitate developing an agent-based modelling and simulation which helps town planners and decision makers to understand the relationship and interaction between economic growth and dynamic land use patterns in their region.
\end{abstract}

Keywords: Regional Economic Growth, Geographical Information System, Urban Sprawl, Firm Demography.

\footnotetext{
'Senioc Lecturer at Deparment of Uitan and Hegional Hinning. Faswlty of Built Environmest. Unizeniti Telnologi Malaysia. Emsil: b-noondinigutromy (Conesponding Author)
} 


\section{INTRODUCTION}

Urban planning and transportation modelling have in common a long history of modelling urban dynamics. These disciplines have however used to some extent different modeling approaches. The integrated land use transportation models have been dominant in transportation research. The core of this modelling approach is a transportation demand model that is applied to a given spatial configuration of land uses. It results in a distribution of traffic, travel times and perhaps congestion. These travel times are then used as input to measure acoessibility. Land use change is then modelled as a function of changing accessibility, and iteratively urban dynamics are then simulated.

It may be argued that the integrated land use transportation models include a richer set of behavioural principles. However, the location decisions of firms which are mainly based on the concept of accessibility do little justice to the results of empirical studies in regional science and economic geography. This suggest that the location decisions of firms are part of their overall business model and influenced by a larger set of considerations, same of which are related to preferences, others to constraints. To avoid these problems, multi-agent models have been advocated as an altemative to these dominant modelling approaches. An agent in this context represents a decision maker that makes location decisions, party independently, partly in reaction to the location decisions of other agents. The philosophy behind this modelling approach is that urban growth patterns emerge as the cumulative effects of these individual decisions. In that sense, multiagent models are assumed to better allow investigating urban land use as a complex system. Models are built in order to understand urban dynamics since these tools, in mimicking part of the urban system, can provide valuable information on the system's behaviour to planners. Despite the potential of agentbased models to simulate urban dynamics, very little progress has been made, especially if ignoring those models claiming to be multi-agent models but which in reality stay very close to conventional integrated land-use transportation models. This is possibly the result of the lack of basis for identifying the characteristics of multiple actors. This paper therefore, preparss a foundation for an agent-based modelling and simulation of urban dynamics while understanding the pattern, behaviour and scale of multiple actors. The paper considers firms entrance and exit in Greater Kunla Lumpur, Malaysia, where the economic growth and urbanisation trend is rapid and attracted a great number of literature (Morshidi $2000)$.

In achieving sustainable development in Malaysia, urbun planning activities have changed from simple objectives to a more complex exercise improving comfort living conditions. This is due to the government initiative to 
introduce development programs to accelerate economic growth and elevate income levels to improve the quality of life of people. Furthermore, with the new trends of economic regional development in Malaysia, it may be relevant to develop a model which simulates growth within the region. Economic growth can be described as changes or increments in the level of production of goods and services in the economy of a country over a period of time. To the extent that economic growth is reflected in urban growth, it is often manifested in changes in land use patterns. In general, some amount of growth can be captured in the existing building stock and associated land use pattems, but increasing growth tends to induce land use change. The problem and difficulty is how to incorporate economic growth in agent-based models. This paper aims to answer this question in the following sections.

\section{URBAN LAND USE AND ECONOMIC GROWTH MODEL}

\section{Understanding Urban Land Use}

Understanding urban and regional growth is important in order to model it since it involves several actors with different patterns of behaviour (Cheng 2003). Urban growth can be defined as the process of growth and decline of urban areas. These urbanization processes tend to be strongly linked to economic development processes. The pattern of concentration of economic activity and its evolution bas been found to be an important determinant of the structure of cities, the organization of economic activity, and national economic growth. Yet, urban growth affects the efficiency of production and economic growth, and the way agents interact and live in cities. Urban growth is related to land use in cities, In order to understand these land use pattern, models have been built to make these relationships explicit.

Early urban models were formulated in the 1950s. However the first operational model of urban land use is widely considered to be developed by Lowry (1964) and is known as "Model of Metropolis". This model was the first generation of models that is based on theories of spatial interaction. The spatial interaction models framework was continued to be developed through the early 1960 s to the mid-1980s when they became mainly replaced by models grounded on random utility theory and an econometrics framework. (Iacono ef al. 2008). This shift also meant a changing focus from aggregate, spatial analysis to disaggregate non-spatial analysis. Starting in the early $1990 \mathrm{~s}$, researchers have dedicated their effort to develop comprehensive urban micro-simulation models, and cell based models which reflect the dynamics of change in urban environments. These modern era models backed with advances in computing 
technology and efficiency, allow researchers to undertake a more complex series of model development, for instance, through the integration of new technology such as GIS to ereate a new generation of models. Figure 1 shows the chronological development of land use and transportation models.

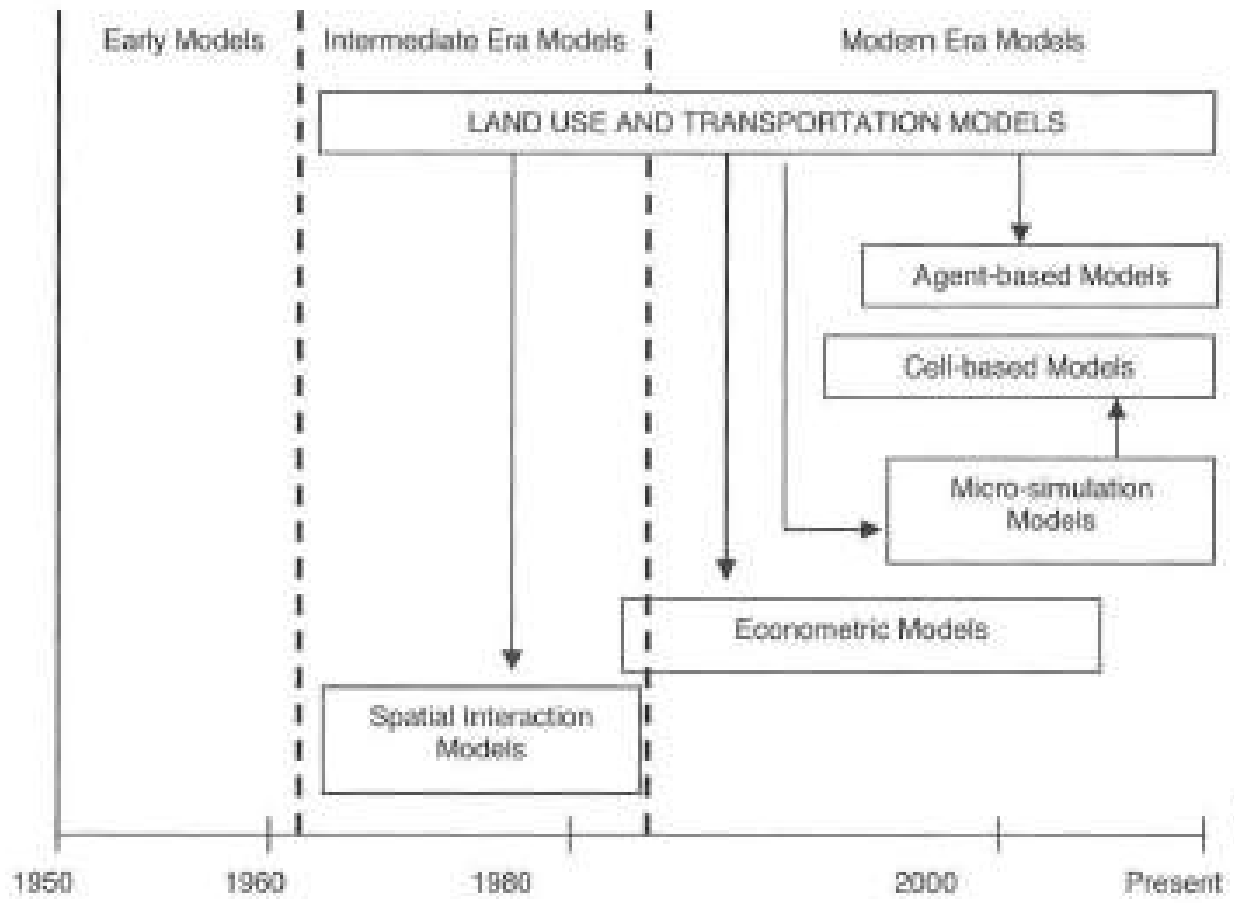

Figute I: Chronological Development of Urban Land Use and Transportation Models

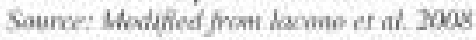

\section{How to Incorporate Economic Growth?}

To address the issues of incorporating economic growth in land use change model, several cellular automata and agent-based models have been develop (Batty \& Xie 1994; Yeh \& Li 2001: Li \& Liu 2008). Although there are differences between models, integrated land use transportation and cellular automata modets typically first estimate a model of economic growth such as a spatial input-output model, sometimes linked to assumptions or a model of external urban growth. These models then predict the impact of change in the economy in one sector or region on other sectors in other regions. This change is assumed to reflect a changing demand for land use. Finally, this additional demand is allocated across locations as a function of accessibility and suitability. The mechanism of including economic growth into these models is hierarchical and aggregate and far removed 
from the premise of agent-based modelling of behavioural realism. The question then is what altemative approach may be employed?

Based on the notion that location decisions are part of their business model and its inherent dynamics, it has been argued that perhaps the demography of firms or firm demography may be valuable approach (van Wissen 2002). This concept focuses on the demographic transformation of firms in the region and its correlation with land use changes. Firm demography can be defined in terms of the lifecycles of a firm which are similar to human lifecycles that consist of birth, death, and changes in the number of employees of the firm. Seminal work on this concept goes back to David Birch's study on 'job generating processes' in the USA (Birch 1979). He advocates that the economic development of a region consists of birth, death, and migration of firms which can be considered as the basic components of development (Van Dijk \& Pellenbarg 2000b). In recent years, firm demography has caught some attention in organisational sociology (Carroll \& Hannan 2000), economics and economic geography (van Wissen 2002), industrial organization (Geroski 1995; Audretsch et al. 1997); (Caves 1998), regional science (Van Dijk \& Pellenbarg 2000a) and transportation (Mocekel 2005). This study decided to use the concept of firm demography, but the concept probably needs some elaboration. Existing models have basically used the concept only to have an accounting system that predicts the future number of firms in particular segments and their size as a function of births, deaths and relocations. To the extent these drivers of change are predicted, often again the well-known aggregate models are used. This remains far from a richer theoretical framework. Hence, the challenge is how to model decisions about growth/decline, start and elosure and relocations as a function of external factors. Identifying the special links between firm dynamics and urban dynamics will give firm demography the connotation of an intermediate concept linked with economic growth.

\section{Malaysia's Urban Planning System and Economic Growth}

Urban planning activities in Malaysia has evolved from the simple objective of improving living conditions to a more complex exercise of facilitating the achievement of sustainable development in the country. This is due to the intensity of development activities that require determining issues such as those relating to location, size and patterns of land utilization.

Table I shows Malaysia's Vision and National Planning System from the year 1947 until now. The vision is the revolutionize government development. The national planning development plan is a written policy document that includes supportive statistical data to define Malaysia's terms of development and that sets the agenda for socio economic change (Bruton 2007). This vision and 
development plan emphasise Malaysia planning strategies for generating sustained economic growth to ensure that the benefits of growth can be shared among all Malaysians in an equitable manner.

Table I: Malaysia's Vision and National Level Planning System

\begin{tabular}{|c|c|c|c|c|c|}
\hline $\begin{array}{c}\text { Plim } \\
\text { Content }\end{array}$ & $1947-1957$ & $1958-1970$ & $1971-1990$ & $1991-20001$ & $2001-2010$ \\
\hline Visicen & $\begin{array}{l}\text { British } \\
\text { Colonial }\end{array}$ & $\begin{array}{l}\text { Old } \\
\text { Ecosomic } \\
\text { Folicy }\end{array}$ & $\begin{array}{l}\text { 1. New } \\
\text { Eoonomic } \\
\text { Policy } \\
\text { 2. Outliae } \\
\text { Perspectis } \\
\text { es Plan I }\end{array}$ & $\begin{array}{l}\text { 1. New } \\
\text { Economic } \\
\text { Policy } \\
\text { 2. Outline } \\
\text { Perspostives } \\
\text { Plan 2 }\end{array}$ & $\begin{array}{l}\text { Natisonal } \\
\text { Vision Policy }\end{array}$ \\
\hline $\begin{array}{l}\text { Planning } \\
\text { at } \\
\text { National } \\
\text { Level }\end{array}$ & $\begin{array}{l}\text { Plians for } \\
\text { Eounomic } \\
\text { Development }\end{array}$ & $\begin{array}{l}\text { Plans for } \\
\text { Economic } \\
\text { Developement }\end{array}$ & $\begin{array}{l}\text { Deviolopment } \\
\text { Plans } \\
\text { Plans } 1.5\end{array}$ & $\begin{array}{l}\text { Developencit } \\
\text { Plans } \\
\text { Plans } 6-7\end{array}$ & $\begin{array}{l}\text { Development } \\
\text { Plans } \\
\text { Malaysia } \\
\text { Plans 8-9 } \\
\text { National } \\
\text { Plovsical Plan }\end{array}$ \\
\hline
\end{tabular}

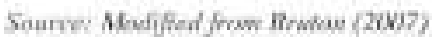

The Malaysian econony has generated an average Gross Domestic Product (GDP) of $6.2 \%$ per annum from 1991 to 2005 and was expected to grow at a healthy rate of $8.5 \%$ a year between 2006 until 2010 (Parliament of Malaysia 2006). With the previous and current economic situation in the country, it explains the relation to firm performance in a later part of the paper. Although this research is not directly related to an economic study, the economic indicators and government policy need to be taken into consideration because firm demography is influenced by these.

\section{GIS AND ABM INTEGRATION}

Currently, the employment of Information and Communication Technology (ICT) is seen as an evolving approach to improve urban governance. GIS is a tool for decision making and for providing planning information. GIS tools have the ability to build complex and interesting spatial models that represent patterns of urban development, although that may take some effort as their script languages are not necessary the best in this regard. At the very least, however, geographic information systems are highly appropriate for spatial data handling and visualization of model output (Davis 2001). Geo-reference is the most important feature of GIS and this functionality is very useful for spatial modelling. Applications based on spatial reference will create better agent-based models 
(Benenson \& Torrens 2004). Meanwhile, agent-based model have the capability to represent the processes underlying a particular phenomenon or activities.

According to Cheng (2003), agent-based modelling (ABM) can be defined as a collection of interacting autonomous agents, each with their own capacities and goals but related to a common environment that can involve communication, such as passing of information from one agent and environment to another. $\mathrm{He}$ also claims that agent-based simulation is ideally suited to explore the implications of nonlinearity in system behaviour and also lends itself to models that are readily scalable in scope and level. In turban systems, Multi Agents are also a useful tool for representing mobile entities in urban environments such as people, households and vehicles (Benenson \& Torrens 2004). They have been used in urban contexts to simulate pedestrian movement in urban environments (Kerridge et al. 2001) and relocate households (Benenson 1998). It is unlikely that a model of urban evolution will need that level of detail, but in any case these examples of agentbased model do indicate that these systems are more appropriate to include a wide variety of behavioural principles and co-evolutionary decision strategies. Therefore, the relation and interaction of firm dynamic and land use changes can be simply detected using agent-based modelling.

GIS technologies are very useful for this study because GIS allow agentbased modellers to relate agents to actual geographic locations. Therefore, the integration of GIS and ABM will enhance the capability of urban simulation techniques (Brown et al. 2005; Parker 2005, Torrens \& Benenson 2005). The integration of ABM and GIS enables exploring how heterogeneous individual decisions of agents translate it into aggregate rates of a phenomenon (Mathur 2007).

Integration of GIS and ABM in the urban dynamics domain has been studied before in several isspects. Gonçalves et al. (2004) for example, recommended a conceptual environment for coupling GIS and ABM simulation tools. Their ABM -GIS model was used to study the impact of a particular policy by modelling the behaviour of industrials under certain circumstances. A Shell for Simulated Agent Systems (SeSAM) was developed as a tool that provides a generic environment for modelling and experimenting in agent-based simulation (Schüle et al. 2004).

The integration of GIS and ABM would ullow the simulation of urban dynamic development and has potential to simulate, display, analyze and present data using a common platform. Multi-agent models have the potential advantage that simulations can be more based on the behavioural of the actors as opposed to statistical data related to spatial units of observation. Relatively, it also will help 
urban development actors (policy makers and urban planner) and other professionals and administrators that are involved in the whole process of implementation to understand and make a clear decision in urban planning development,

\section{STUDY AREA}

The development of economic regions is one of the forms of the national mission in Vision 2020 motivated by Malaysia's former Prime Minister Dr. Mahathir. The initiative of economic development areas was inspired by the successful Klang Valley region development which is known as the heartland of Malaysia's industry and commerce. With diverse development coneepts, it aims to achieve the goal of accelerating economic growth and development, and improving the quality of life for the people in these regions. Five new economic development corridors throughout the country were initiated and are being developed since 2005: Iskandar Development Region (IDR), North Corridor Economic Region (NCER), East Corridor Economic Region (ECER) Sabah Development Corridor (SDC) and the most recent The Sarawak Corridor of Renewable Energy (SCORE). Thus, with these economic development regions, it is realistic to develop a model that simulates growth within these regions. Yet, after considering data availability, it was decided to focus on the Klang Valley region and specifically on Kuala Lumpur as the study area.

\section{Lecation}

Klang Valley is a region in Malaysia which is comprised of Kuala Lumpur and its fringes and neighbouring cities and towns in the state of Selangor, Klang Valley has no ofticial boundary, yet it is currently comprised of six distriets which are Kuala Lumpur, Putrajaya, Gombak, Hulu Langat, Klang and Petaling (Figure 2). The physical site of the area was encouraged by the development of commercial, industrial and residential activities which made Klang Valley grow rapidly. With a population of 5.78 million people (Department of Statisties Malaysia, 2008) and areas covering up to $2,826 \mathrm{~km}^{2}$. Klang Valley has the most urbane transportation hierarchy in Malaysia. Rather than a road system, integrated rail transport which consists of monorail, electrified commuter, light rail transit (LRT) and Express Rail Link (ERL) are built for Klang Valley's residents and workers to commute within the region which make it the most important region in Malaysia. This region is also served by two airports: the Kuala Lumpur International Airport (KLIA) in Sepang, which is the main intemational airport for Malaysia, and Sultan 
Abdul Aziz Shah Airport in Subang, which handles general aviation and turboprop domestic flights (2010).

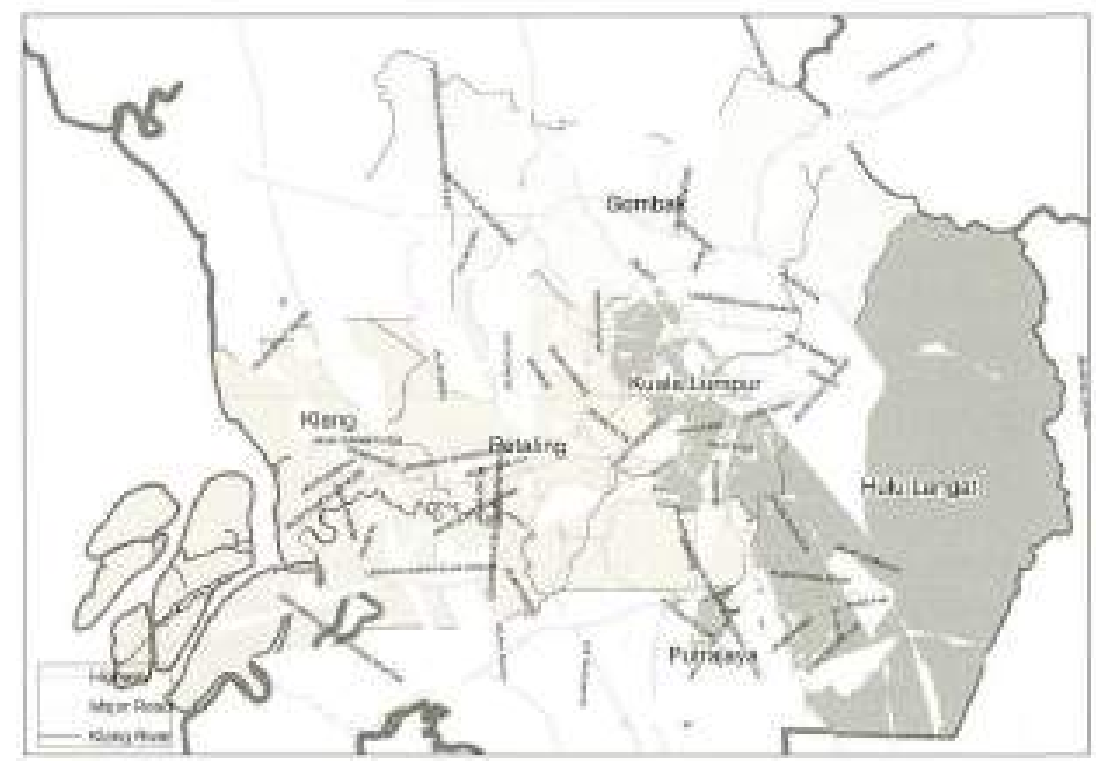

Figure 2: Klang Valley Region

\section{GIS DATABASE DESIGN AND DEVELOPMENT}

\section{Data Source}

This study will utilize data from various sources, including GIS spatial and attribute data. The land use data of Klang Valley is obtained from Klang Valley Federal Territory (KVFT), demographic data from the Department of Statistics Malaysia and firm data which consist of companies registered in Malaysia are acquired from Company Commission of Malaysia (CCM). Other data to support the application such as transportation, administration and physical data are obtained from KVFT. The data are collected by visiting the targeted agency. In order to get accurate and precise data, every single spatial data is required to have a standard geo-reference. Thus, the data needs to be edited and manipulated. Attribute data were collected from various sources such as compilation of scientific reports, collections from site surveys, various digital forms data in multiple formats such as database, spreadsheet tables, and internet as well as raw data. All these data were adapted to a standard format and stored in a relational database management system which has the ability to relate to other databases. 


\section{Data Classification}

The structure of the GIS database for this study is focused on the needs of this study: land use development. For this study, there are several data layers in the database (Figure 3).

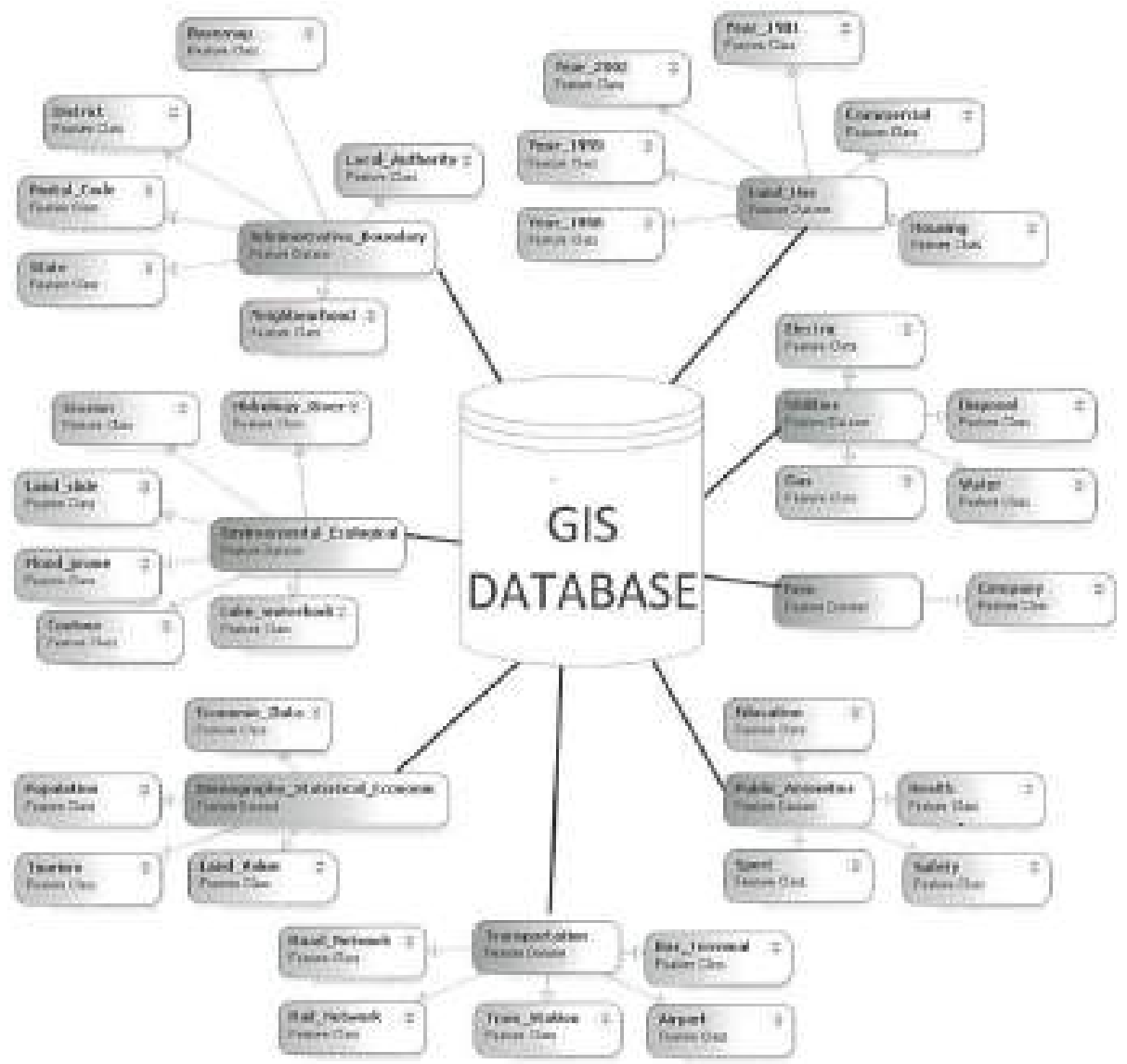

Figure 3: GIS Database

\section{FIRM DATA ANALYSIS}

The first stage of firm data unalysis was conducted for the years 1990 until 2007. This preliminary analysis served as a guide to decide on the method that will be used for later periods of fim data. 


\section{Geocoding Firm Addresses}

The firm data which were obtained from CCM were in spread sheet format. In order to display firm locations in spatial environments, geocoding was used. Geocoding or address matching is the process of assigning a location, usually in the form of coordinate values, to an address by comparing the descriptive location elements in the address to those present in the reference material (ESRI 2003). Based on the data, addresses come from common address formats of a company premise number followed by the street name, postal zone and area. Geocoding the address is based on a linear interpolation of an address based on the street segment in a reference of street file. In this study we geocode 62,605 firm addresses in the database. Addresses were geocode to the street name and assigned longitude and longitude coordinate using Kuala Lumpur street address locator which was created using ArcGIS software version 9.2. To geocode addresses, company data were the input and road information were the key field for matching the address. Addresses were matched using a minimum score of 10 , spelling sensitivity of 10 and side offset of 10. With ArcGIS, the result of unmatched geocoding can be rechecked by using interactive re-matching function where the address can be reviewed and corrected on a case by case basis. Results with a match rate of greater or equal $(\gg \Rightarrow)$ were positively accurate.

\section{Result}

From the 62,605 firm in the database, a match rate of $86 \%(n=53,626)$ match with score 80 to $100,14 \%(n-8,979)$ match candidate with seore not more than (<) 80 were discovered. From the overall matching process, $17 \%(n=10,394)$ are matched with candidate ties. In general, it can be concluded that most of the geocoded address fall close to the reference data locations.

\section{FIRM DYNAMIC AND PRODUCTIVITY}

This analysis covers firms in the Kuala Lumpur area between 1990 and 2007. Figure 4 shows the dynamic performance of firms operating between 1990 and 2007. In total, there are 62,605 firms including unknown type of firms in the Kuala Lumpur area. An unknown type firm in this study is described as a firm which is not adequately define by CCM. As can be seen in Figure 4, there were three peak years of firm growth: 1995, 2000 and 2004. From year 1995 onwands, the growth of new firms started to decline especially from 1997 to 1999 dae to the global financial crisis. Unknown type firms have shown a rise and decline similarly to the trends observed for new firm's birth. 


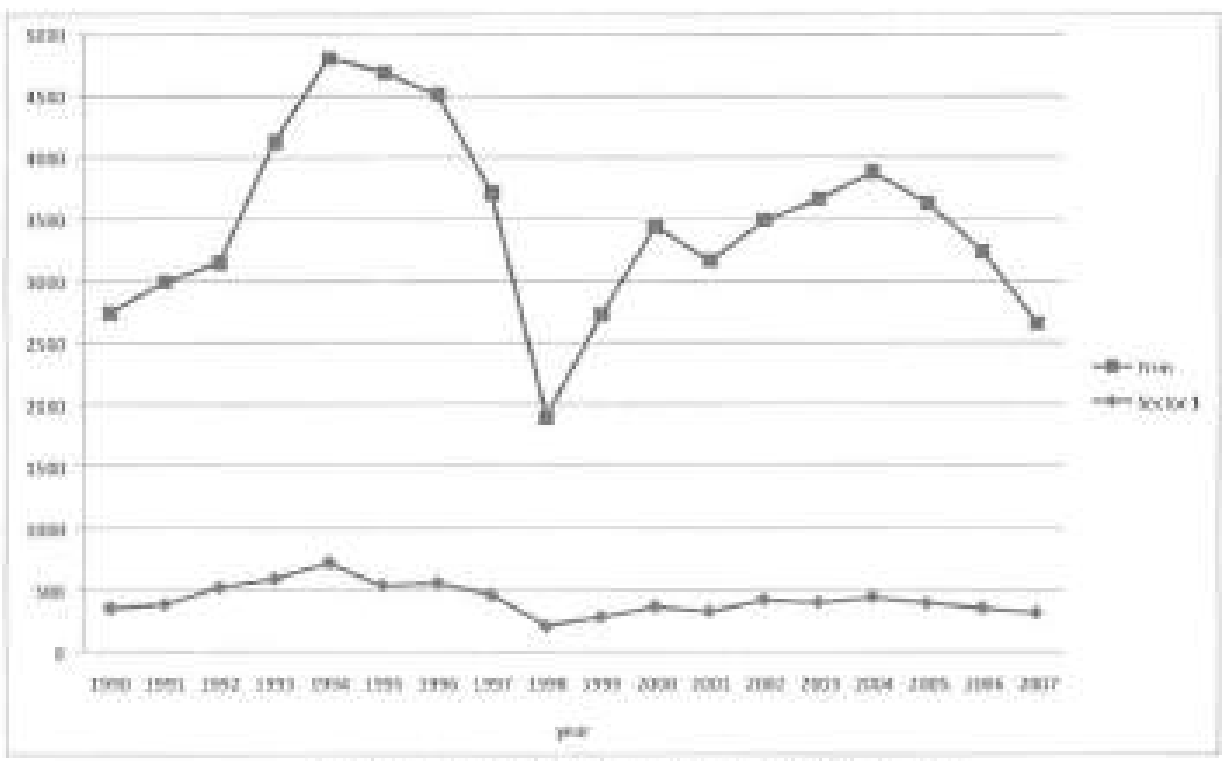

Figure 4: Firm performance from 1990 to 200 ?

The trade sector including firms, playing a role in generating output, income, employment and foreign exchange eamings which contributed to excellent economic performance. As shown in Figure 4, from the year 1990 until 2007, the number of births of firms increased every year in the study area. The increases of new firms are in line with Malaysia's Business Cycle Tums between 1990 and 2007 as shown in Figure 5. The business cycle is influenced by cyclical fluctuations in economic activities or processes, whereby these cconomic activities or processes can have widely conflicting temporal relationships to the business cycle (Department of Statistics Malaysia 2009). 


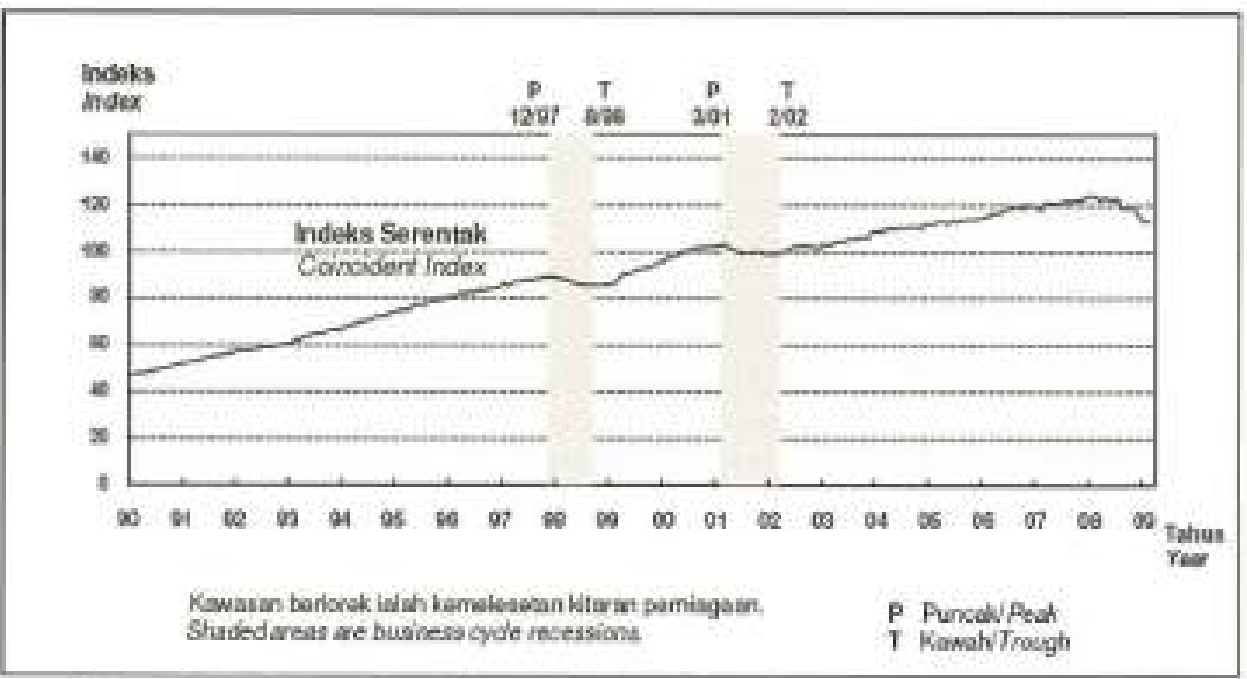

Figure 5: The Coincident Index and Malaysia Business Cycle Turas 1990-2009.

Sowree ; Deparmenes af Shatistics Malaysia 2009

From 1990 to 2007, Malaysian economic development was under The Sixth to Ninth Malaysia Plan and Second Outline Perspective Plan. The tride sector including firms, playing a role in generating output, income, employment and foreign exchange earnings which contributed to excellent economic performance.

From Figure 6, it can be seen that sector 9 (Financing, Insurance, Real Estate, Investment and Business Services) encompasses the largest share of new firms $(35.1 \%$ ) which provided the impetus for economic growth during 1990 to 2007, followed by sector 7 (Wholesale and Retail trade, Restaurant and Hotel) with $30.1 \%$, sector 10 (Community, Social and Personal Services) with $6.6 \%$, sector 6 (Construction) with $6.3 \%$, sector 4 (Manufacturing) with $4.3 \%$, sector 8 (Transportation and Communication) with $4.5 \%$ and sector 2 (Agriculture, Hunting. Forestry and Fishing) with $0.5 \%$.

Sectors 9 and 7 which make up the service sector cover $65 \%$ of firms, which are more than two-thirds of overall firm births in Kuala Lumpur. The rapid expansion of these sectors was due to the growth of four service industry groups in Malaysia-finance, insurance, real estate and business services; estate and business services; wholesale and retail trade, hotels and restaurant; and transport, storage and communications-which accounted for more than $60 \%$ of all new jobs in Kuala Lumpur (Morshidi 2000). Firm births in Sector 3 (Mining and Quarrying) and sector 5 (Electricity, Gas and Water) shows a very modest growth 
in this period of only $0.3 \%$. Although firm births in sector 5 are small, it is the country's engine of growth. Other sectors, especially sector 2, remain significant and an important component of the Malaysian economy.

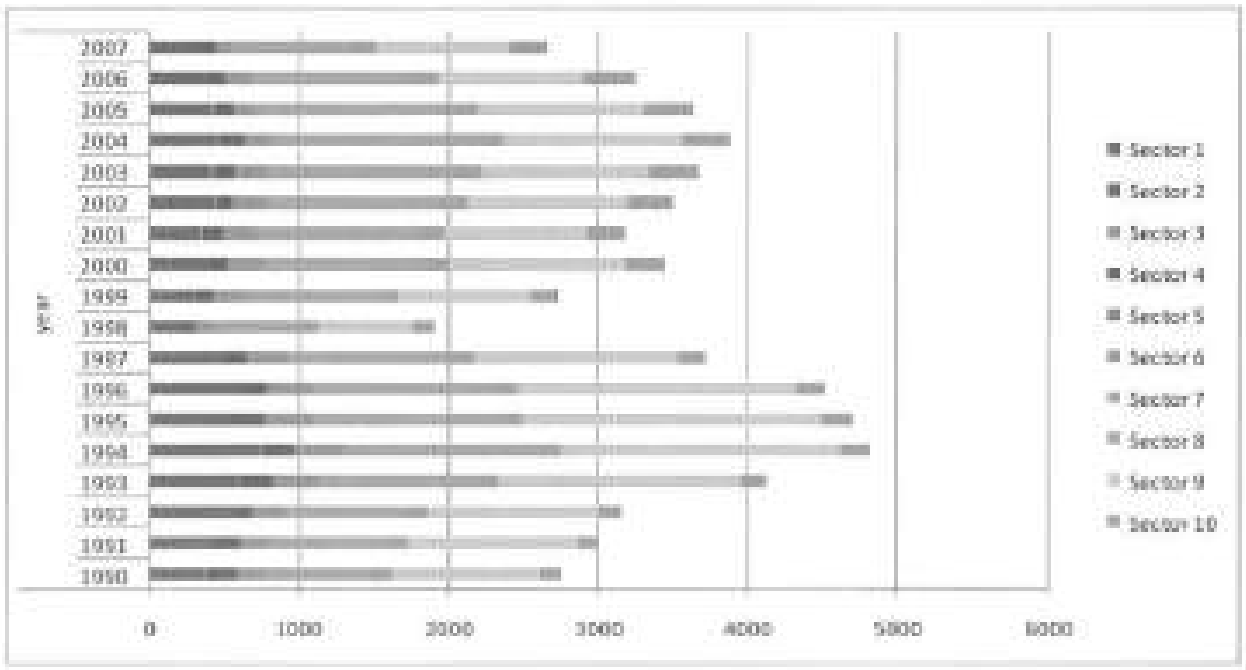

Figure 6: Firm Performance by Sector (1990-1997)

\section{CONCLUSION AND DISCUSSION}

This study is carried out with the objective of preparing a foundation for an agentbased modelling and simulation of urban dynamics while understanding the pattern, behaviour and scale of multiple actors. Using the findings of this study, the model will be developed using data of the Greater Kuala Lumpur. In general, the success of multi-igent model will among other factors depend on data availability and richness of behavioural concepts. In the early stage of development, there are needs to explore these issues and make strategic decisions. This paper documents this process by discussing some general literature, database development and initial analysis of the available data. The existing literature suggest that agent-based modelling is a reliable alternative to more commonly used cellular automata models and integrated land use transportation models in the sense that in principle they allow for richer behavioural principles and the treatment of interdependent location strategies of multiple actors and stakeholders.

For this study, the use of GIS tools assisted in data handling and visualization, while the trend of developing planning support systems based on GIS technology can also be supported. The very integration of GIS and ABM will have great impact on the process. A main problem of developing this system, the 
modelling of economic development as a bottom-up development process has been emphasised. It is not immediately clear how this problem may be solved in a non-traditional way, but perhaps the concept of firm demography may provide the key to a solution. Finally, model opportunities are limited to data availability. The data sources collected from different authorities and the data fusions described and planned, however, suggest that for the present study area, an interesting set of (temporal) data is available.

\section{Acknowledgment}

The authors would like to thank the Klang Valley Federal Territory, Universiti Teknologi Malaysia and Department of Statistics Malaysia for their permission to use the data for this research paper. 


\section{REFERENCES}

Audretsch, D, B, Houweling, P., \& Thurik, A, R. (1997). New Finu Sirvival: Industry versus Firm Effects, 97-063/3. Tinbergen Institute. Tinbergen Institute Discussion

Papers. Ref Type: Serial (Book,Monograph)

Batty, M. and Y. Xie. (1994). From Cells to Cities. Environment and Planning B: Planning and Design, 21, 31-48.

Benenson, L. \& Torrens, P. M. (2004). Geosimalation: Automata-based Modelling of Urban Phenomene. Tel Aviv University, Israel and University of Utah, USA.

Benenson, L. (1998). Muliti-agent Simulations of Residential dynamics in the City. Computers, Environment and Urban Systems, 22, 25-42.

Birch, D. L. (1979). The Job Generation Process, MIT Program on Neighborhood and Regional Change, Cambridge, MA.

Brown, D. G., Riolo, R., Robinson, D. T., North, M., \& Rand, W. (2005), Spatial Process and Data Models. Toward Integration of Agent-based Models and GIS. Journal of Geographical Systems, 7, 25-47.

Bruton, M. J. (2007), Malaysia : The Planning of a Nation. PERSADA Malaysia,

Carroll, G. \& Hannan, T. M. (2000), The Demograplyy of Organizations and Industries. Princeton: Princeton U. Press.

Caves, R. E. (1998). Industrial Organization and New Findings on the Turnover and Mobility of Firms, Journal of Economic Literature, 36, 1947-1982.

Cheng, J. (2003). Modeling Spatial \& Tenporal Urban Growth. International Institute for Geo-information Science and Earth Observation, Enschede Netherlands.

Davis, B. E. (2001). GIS : A Visual Approach. Canada: Onword Press.

Department of Statistics Malaysia. (2008), Viral Stafistics Malaysia 2008 Department of Statistics Malaysia.

Department of Statistics Malaysia, (2009), Malaysia Economic Indicators: Leading. Coincident and Lagging Indices Year 2009. Department of Statistics Malaysia.

Geroski, P. A. (1995). What do we know about entry? International fournal of Industrial Organization, $13,421-440$.

Gonçalves, A. S. Rodrigues, A. and Correia, L, (2004). Multi-Agent Simulation within Geographic Information Systems. In 5 th Workshop on Agent-Based Simulation, ABSO4.

lacono, M., Levinson, D., and El-Geneidy, A. (2008). Modeis of Transportation and Land Use Change: A Guide to the Territory. Journal of Planning Literature, 1-18. 
Karadimas, N. V., Rigopoulos, G. and Bardis, N. (2006). Coupling Multiagent Simulation and GIS - An Application in Waste Management. WSEAS Transactions on Systems, 5, 2367-2371.

Kerridge, J., Hine, J. and Wigan, M. (2001). Agent-based Modelling of Pedestrian Movements: the Questions that Need to be Asked and Answered. Environment and Planting B: Plaming and Design, 28, 327-341.

Li, X. and Liu, X, (2008). Embedding Sustainable Development Strategies in Agent-based Models for Use as a Planning Tool. International Jorarnal of Geographical Information Science, 22(1), 21-45.

Lowry, I. S. (1964). A Model of Metropolis. Santa Monica: CA: Rand Corporation. Mathur, P. (2007). Agent-based Modeling of Urban Phenomena in GIS.

Moeckel, R. (2005). Microsimulation of Firm Location Decision. In 9th International Conference on Compaters in Urban Planaing and Urban Management (CUPUM) London.

Morshidi, S. (2000). Globalising Kuala Lumpur and the Strategic Role of the Producer Services Sector, Urban Studies, 37 (12), p.2217-2240.

Parker, D. C. (2005). Integration of Geographic Information Systems and AgentBased Models of Land Use: Challenges and Prospects. In D.Maguire, M. Goodchild, \& M. Batty (Eds.), GIS, Spatial Analysis and Modeling (pp. 403-422). ESRI press, Redlands, CA.

Schüle, M., Herrler, R, and KJUgl, F. (2004), Coupling GIS and Multi-agent Simulation - Towards Infrastructure for Realistic Simulation. In J.G.Carbonell \& J.Siekmann (Eds.), Mutriagent System Technologies: Second German Conference, MATES 2004, Erfurt, Germany, September 29-30, 2004. Proceedings (pp. 228-242). Springer Berlin / Heidelberg.

Torrens, P. M. and Benenson, L. (2005). Geographic Automata Systems. International Journal of Geographical Information Science, 19, 385-412.

Van Dijk, J. and Pellenbarg, P. H. (2000a). Spatial Perspectives on Firm Demography. Regional Sclence, 79, 107-110.

Van Dijk, J. \& Pellenbarg, P. H. (2000b). The Demography of Fims: An Introduction. In P.H.Pellenbarg \& J. Van Dijk (Eds.), Demography of Firms: Spatial Dynamies of Firm Behaviour. Netherlands Geographical Studies No 262,

Van Dijk, J. and Pellenbarg, P. H. (2000c). The Demography of Firms: Progress and Problems in Empirical Research. In P.H.Pellenbarg \& J. Van Dijk (Eds.). Demography of Firms: Spatial Dynamics of Firm Behaviour. Netheriands Geographical Studies No, 262.

van Wissen, L. J. G, (2002). Demography of the Firm; A Useful Metaphor? European Journal of Population, 18, 263-279.

Yeh, A.G.O. and X. Li (2001). A Constrained CA Model for the Simulation and Planning of Sustainable Urban Forms by using GIS. Environment and Planning B: Planning and Design, 28, 733-753. 


\section{Internet Source:}

ESRL. (2003). ArcGiS 9 Geocoding Rule Base Developer Guide. webhelp.esri.com/arcgisdesktop 19.2 /pdDGeocoding Rule Base Develope r_Guide.puff [On-line]. Available: http:/webhelp,esri.com/arcgisdesktop/9.2/ndficicoonding Rule Base_De veloper Guide.pdif

Parliament of Malaysia. (2006). Speech by the Prime Minister Yab Dato' Seri Abdullah Bin Haji Ahmad Badawi: Introducing The Motion To Table, The Ninth Malaysia Plan, 2006-2010, In The Dewan Rakyat, 31 March 2006. parlimen_gov.my/news/eng-ucapan_rmk9.pdf [On-line]. Available: www.parlimen.gov.my/newsieng-ucapan rmk9.pdf

Sultan Abdul Aziz Shah Airport. (2010). Wikipedia [On-line]. Available: http://en,wikipedia,org/wiki/Sultan Abdul Aziz Shah_Airport 